\title{
Studi Pengaruh Pemanasan Awal pada Pengelasan Ulang Baja ASTM A36 Akibat Reparasi Terhadap Sifat Mekanis Menggunakan Proses Las FCAW
}

\author{
Bimantara Haryudanto Pangaribowo, Wing Hendroprasetyo Akbar Putra \\ Departemen Teknik Perkapalan, Fakultas Teknologi Kelautan \\ Institut Teknologi Sepuluh Nopember (ITS) 60111 Indonesia \\ e-mail: winghendroprasetyo@gmail.com
}

\begin{abstract}
Abstrak-Dalam industri perkapalan, sering terjadi kesalahan dalam proses pengelasan sehingga perlu dilakukan replating. Pemanasan awal (preheat) merupakan metode perlakuan panas yang dilakukan dalam proses pengelasan dengan tujuan memperlambat laju pendinginan pada logam las dan logam dasar sehingga menghasilkan struktur logam yang lebih ulet. Tujuan dari Penelitian ini untuk mengetahui pengaruh dilakukannya pemanasan awal pada pengelasan ulang dan sifat mekanis pada logam las akibat pengelasan ulang.

Dalam penelitian ini dilakukan pengelasan ulang sebanyak tiga kali dengan perlakuan pemanasan awal. Suhu pemanasan awal maksimum sebesar $200^{\circ} \mathrm{C}$ dan suhu interpass maksimum sebesar $200^{\circ} \mathrm{C}$. Proses pengelasan yang digunakan untuk pengelasan baja karbon ASTM A36 adalah flux cored arc welding (FCAW). Selanjutnya dilakukan pengujian yang mencakup: uji tarik, uji kekerasan, uji impact, dan uji metalografi. Berdasarkan hasil pengujian diketahui bahwa nilai kuat tarik tertinggi sebesar $607.33 \mathrm{~N} / \mathrm{mm}^{2}$ pada material dengan satu kali pengelasan (no rework) dan nilai kuat tarik terendah sebesar $550.88 \mathrm{~N} / \mathrm{mm}^{2}$ pada material dengan empat kali pengelasan ( $3 \times$ rework). Nilai kekerasan tertinggi terdapat pada daerah weld metal dengan material dengan satu kali pengelasan (no rework) sebesar 182.4 HV dan nilai kekerasan terendah terdapat pada daerah base metal dengan material dengan empat kali pengelasan ( $3 \times$ rework) sebesar $138.8 \mathrm{HV}$. Hasil pengujian impact pada weld metal diketahui bahwa energi absorb semakin besar, dengan nilai energi absorb terendah pada material dengan satu kali pengelasan (no rework) sebesar 132 Joule dan nilai energi absorb tertinggi pada material dengan empat kali pengelasan ( $3 \mathrm{x}$ rework) sebesar 139 Joule. Dari hasil uji metalografi dapat diamati bahwa butiran pearlite dan ferrite terbentuk semakin besar dan rapat karena terdapat pengaruh panas akibat dilakukan pengelasan ulang dan proses pemanasan awal (Preheat), dimana semakin besar ukuran butir maka akan semakin kecil angka kekerasan pada sebuah material.
\end{abstract}

Kata Kunci-ASTM A36, Jumlah Rework, Preheat, Kuat Tarik, Kekerasan, Impact, Metalografi.

\section{PENDAHULUAN}

$\mathrm{I}$ NDUSTRI perkapalan yang semakin maju seperti sekarang, dalam proses penyambungan material seperti baja dilakukan dengan teknologi pengelasan. Pengelasan dan penyambungan adalah teknologi manufaktur dasar yang diperlukan untuk setiap sektor industri. Dalam proses reparasi kapal dan replating tidak lepas pada proses pengelasan ulang atau rework dikarenakan adanya kesalahan yang terjadi dalam pengerjaan. Akibat dari proses pengelasan dapat menyebabkan terjadinya cacat las, deformasi ataupun retak las yang mengharuskan dilakukannya perbaikan salah satunya dengan pengelasan ulang.

Baja ASTM A36 merupakan salah satu yang tergolong kedalam baja yang dapat diberikan perlakuan panas sehingga dapat dilakukan pemanasan awal ketika akan dilakukan pengelasan. Baja ASTM A36 termasuk kedalam baja karbon rendah dengan kandungan karbon \%C $<3 \%$ dan unsur penyusun utamanya terdiri dar besi (Fe) dan karbon (C) serta unsur lain seperti $\mathrm{Mn}, \mathrm{Si}, \mathrm{Ni}, \mathrm{Cr}$ dan lain sebagainya dalam persentase kecil. Baja karbon rendah mempunyai sifat mekanis yang baik, kekuatan tarik relatif tinggi yaitu antara 415 - 550 MPa (60.000 - 80.000 psi), ketangguhan baik dan relatif ulet.

Preheat atau pemanasan awal merupakan panas yang diberikan kepada logam induk pada suhu yang tepat sebelum dilakukan pengelasan. Salah satu tujuan dari preheat adalah memperlambat laju pendinginan pada logam las dan logam dasar sehingga menghasilkan struktur logam lebih ulet yang memiliki ketahanan terhadap retak lebih besar.

Dalam bidang perkapalan pada sambungan las pelat lunas sering terjadi kesalahan pengelasan. Dengan demikian dapat mengakibatkan berubahnya struktur metalurgi dan kekuatan dari material baja. Sehingga perlu adanya perlakuan rework. Apabila kesalahan dalam proses pengelasan dilakukan berulang kali, maka perlu dilakukan multiple rework dan dilakukan pengujian yang sesuai untuk mengetahui kekuatan material baja pada daerah weld joint. Untuk mengurangi terjadinya perbedaan temperatur daerah las pada proses pengelasan, dilakukan pemanasan awal pada material baja ASTM A36. Berdasarkan permasalahan yang ada, maka tugas akhir ini dilakukan untuk mengetahui pengaruh preheat terhadap pengelasan ulang baja ASTM A36 ditinjau dari sifat mekanik pada pelat lunas.

\section{TINJAUAN PUSTAKA}

\section{A. Teori Dasar Pengelasan}

Definisi pengelasan menurut American Welding Society adalah proses penyambungan logam atau non logam yang dilakukan dengan memanaskan material yang akan disambung hingga temperatur pencairan yang dilakukan dengan atau tanpa menggunakan tekanan (pressure), atau dengan atau tanpa menggunakan logam pengisi (filler). Dari definisi tersebut dapat diambil pengertian jika pengelasan merupakan proses penyambungan logam atau non logam yang dilakukan dengan memanaskan daerah setempat yang 
akan disambung hingga mencair dan selanjutnya terjadi ikatan metalurgi pada logam tersebut[1].

Pengelasan adalah proses penyambungan secara metalurgi dengan mengaplikasikan beberapa jenis sumber panas. Pengelasan juga dapat diartikan sebagai "sebuah proses penyambungan yang menghasilkan penggabungan dari material-material dengan memanaskannya hingga temperatur pengelasan dengan atau tanpa adanya tekanan atau hanya dengan menggunakan tekanan, dan dengan atau tanpa penggunaan logam pengisi,"[2].

\section{B. Baja Karbon A36}

ASTM A36 memiliki nilai yield strength yang lebih rendah dibandingkan Cold Rolled Steel C1018 (54.000 psi), hal tersebut membuat ASTM A36 lebih mudah untuk dibentuk. Pada Tabel II.1 merupakan komposisi kimia yang terdapat dalam ASTM A36. ASTM A36 biasa digunakan dalam bentuk seperti Rectangle bar, Circular rod, Square bar, $\mathrm{H}$ beams and I-beams[3].

Sifat baja karbon sangat tergantung pada kadar karbon. Oleh karena itu, baja jenis ini dikelompokkan kedalam tiga kelompok besar berdasarkan kadar karbon yang terkandung di dalamnya. Baja Karbon Rendah (Low Carbon Steel/Mild steel), kadar karbon sampai $0.30 \%$. Strukturnya terdiri dari ferrit dan sedikit perlit, sehingga baja ini kekuatannya relatif rendah, lunak tetapi keuletannya tinggi. Baja ini tidak dapat dikeraskan, kecuali dengan pengerasan permukaan.

Baja Karbon Menengah (Medium Carbon Steel), kadar karbon $0.30-0.70 \%$ masih terdiri dari ferrit dan perlit juga, dengan perlit cukup banyak, sehingga baja ini lebih kuat dan keras, serta dapat dikeraskan tetapi getas. Baja Karbon Tinggi (High carbon steel), kadar karbon lebih dari 0.70\% lebih kuat dan lebih keras lagi, tetapi keuletan dan ketangguhannya rendah. Pada baja karbon apabila semakin besar kandungan karbonnya maka material akan semakin kuat tetapi ketangguhannya menurun[3].

Tabel 1.

Komposisi Kimia ASTM A36

\begin{tabular}{|c|c|}
\hline Element & Content \\
\hline Carbon, C, max, \% & $0.25 \%$ \\
\hline Copper, Cu, min, \% & $0.2 \%$ \\
\hline Iron, $\mathrm{Fe}$ & $98 \%$ \\
\hline Manganese, Mn, \% & $0.8 \%$ \\
\hline Phosphorus, P, max, \% & $0.03 \%$ \\
\hline Silicon, Si, \% & $0.4 \%$ \\
\hline Sulfur, S, max, \% & $0.03 \%$ \\
\hline
\end{tabular}

\section{Preheat atau Pemanasan Awal}

Definisi preheat menurut AWS (American Welding Society) adalah panas yang diberikan kepada logam yang akan dilas untuk mendapatkan dan memelihara preheat temperature. Sedangkan preheat temperature sendiri definisinya adalah suhu dari logam induk (base metal) disekitar area yang akan dilas, sebelum pengelasan itu dimulai. Pada multipass weld definisi preheat temperature adalah suhu sesaat sebelum pengelasan pada pass selanjutnya dimulai. Pada multipass weld disebut juga sebagai interpass temperature (suhu antar pass)[1].

Pemanasan awal atau preheat merupakan panas yang diberikan kepada suatu logam yang akan dilas. Preheat temperature merupakan suhu dari logam induk (base metal) disekitar area yang akan dilas, sebelum pengelasan itu dimulai. (AWS, 2015). Terdapat empat alasan utama untuk memanfaatkan perlakuan preheat[4]:
1. Memperlambat laju pendinginan pada logam las dan logam dasar sehingga menghasilkan struktur logam lebih ulet yang memiliki ketahanan terhadap retak yang lebih besar

2. Memungkinkan hidrogen dapat terdifusi keluar sehingga mengurangi potensi retak

3. Mengurangi tegangan sisa dalam logam las dan pada daerah HAZ

4. Mengurangi resiko patah getas dan meningkatkan ketangguhan logam las

Laju pendinginan setelah pengelasan dipengaruhi oleh besarnya temperatur preheat, dimana semakin tinggi temperatur menyebabkan pendinginan semakin lama dan kekerasan mikrostruktur menjadi lebih rendah. Hal tersebut ditunjukkan pada Gambar 1.

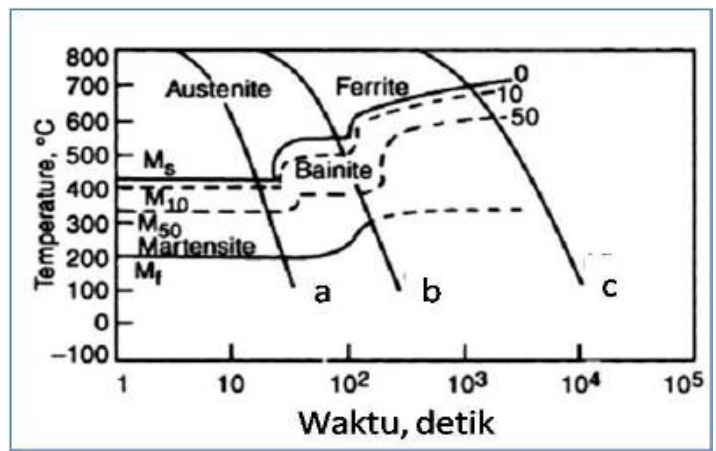

Gambar 1. Diagram Continous Cooling Transformation

\section{Flux Cored Arc Welding (FCAW)}

Pengelasan Flux Cored Arc Welding adalah pengelasan yang menggunakan panas dari busur listrik yang dihasilkan antara filler metal yang kontinyu dari benda kerja. Pengelasan FCAW hampir sama dengan GMAW yang membedakan adalah pada FCAW menggunakan electrode tubular yang didalamnya terdapat flux yang akan berfungsi sebagai gas pelindung sedangkan pada GMAW menggunakan solid wire. Flux yang ada di dalam electrode akan memberikan perlindungan pada molten weld pool terhadap udara luar, memperbaiki kekuatan karena reaksi kimia dan campuran, memperbaiki weld shape[5].

1) Keunggulan pengelasan FCAW

- Proses pengelasan lebih cepat dibandingkan dengan SMAW, karena pada FCAW tidak perlu sering mengganti kawat las karena sudah dalam bentuk wire roll yang panjang.

- FCAW merupakan jenis mesin las yang otomatis dan semiotomatis sehingga lebih mudah digunakan.

- FCAW memiliki perlindungan :

a. Self shielding FCAW (perlindungan sendiri), yaitu merupakan proses melindungi logam las yang mencair dengan menggunakan asap dari hasil penguapan atau reaksi dari inti fluks.

b. Dual shielding FCAW (perlindungan ganda) yaitu perlindungan logam las yang mencair dengan menggunakan flux dan asap.

\section{E. Sifat Mekanik}

Sifat mekanik adalah salah satu sifat terpenting karena menyatakan kemampuan suatu bahan untuk menerima beban/gaya sampai menimbulkan kerusakan pada bahan tersebut. Beberapa sifat mekanik yang penting adalah:[6]

- Kekuatan (strength) menyatakan kemampuan bahan untuk menerima tegangan tanpa menyebabkan patah. Ada banyak jenis kekuatan seperti kekuatan tarik, kekuatan 
geser, kekuatan torsional, kekuatan impak dan kekuatan kelelahan.

- Kekerasan (hardness) menyatakan kemampuan bahan untuk tahan terhadap penggoresan, pengikisan, indentensi atau penetrasi. Kekerasan logam juga memungkinkan pendekatan pada kekuatan tariknya.

- Ketangguhan (toughness) menyatakan kemampuan untuk menyerap sejumlah energi tanpa mengakibatkan kerusakan. Selain itu juga dapat dikatakan sebagai ukuran banyaknya energi yang diperlukan untuk mematahkan suatu benda kerja pada suatu kondisi tertentu.

- Kelelahan (fatigue) merupakan kecenderungan dari logam untuk patah bila menerima tegangan berulangulang yang besarnya masih jauh dibawah kekuatan elastisnya. Kelelahan logam disebabkan oleh tindakan mekanik siklik atau berulang pada daerah yang sama.

- Kekenyalan (ductility) merupakan kemampuan bahan untuk menerima tegangan tanpa mengakibatkan terjadinya perubahan bentuk yang permanen setelah tegangan dihilangkan. Dengan kata lain kekenyalan menyatakan kemampuan bahan untuk kembali ke bentuk dan ukuran semula setelah menerima beban yang menimbulkan deformasi.

\section{F. Hall Petch Equation}

Penguatan batas butir (atau penguatan Hall-Petch) adalah metode memperkuat material dengan mengubah ukuran kristal (butir) rata-rata. Jadi, dengan mengubah ukuran butir satu dapat mempengaruhi gerakan dislokasi dan menghasilkan kekuatan. Misalnya, perlakuan panas setelah deformasi plastik dan mengubah laju pemadatan adalah cara untuk mengubah ukuran butir[7].

Hubungan antara tegangan luluh dan ukuran butir dijelaskan secara matematis oleh persamaan Hall-Petch:

$$
\sigma_{\mathrm{y}}=\sigma_{\mathrm{i}}+\frac{\mathrm{k}_{\mathrm{y}}}{\sqrt{\mathrm{D}}}
$$

Telah diamati secara eksperimental bahwa struktur mikro dengan kekuatan luluh tertinggi adalah ukuran butiran sekitar $10 \mathrm{~nm}(3,9 \times 10-7 \mathrm{in})$, semakin kecil ukuran butir, semakin kecil tekanan tolakan yang dirasakan oleh dislokasi batas butir dan semakin tinggi tegangan yang diperlukan untuk menyebarkan dislokasi melalui material.

\section{METODOLOGI PENELITIAN}

\section{A. Tahap Pembuatan Spesimen Uji}

Pada tahap ini, dilakukan pengadaan material yang akan digunakan untuk penelitian. Material yang dipersiapkan adalah baja ASTM A36 dengan ukuran 400x150x16 mm sejumlah empat buah dan 400x150x14mm sejumlah empat buah. Sebelum dilakukan pengelasan material tersebut dilakukan pembuatan bevel single $v$ sebesar $60^{\circ}$. Selanjutnya material akan di las metode FCAW dengan elektroda E71T1. Sebelum dilakukan pengelasan, material dilakukan pemanasan awal (preheat) sebesar $200^{\circ} \mathrm{C}$ dan selanjutnya dilakukan pengelasan. Variasi pengelasan mencakup no rework, 1 x rework, 2 x rework dan 3 x rework.

\section{B. Tahap Pengujian}

Pengujian yang dilakukan meliputi uji tarik, kekerasan, impact, dan metalografi. Pengambilan test piece untuk dilakukan pengujian didasarkan pada BKI[8]. Pada pengujian tarik diambil 2 spesimen untuk setiap proses pengelasan, pengujian impact diambil 3 spesimen untuk setiap proses pengelasan dengan notch pada weld metal, pengujian kekerasan dan metalografi diambil 1 spesimen setiap proses pengelasan. Untuk pengujian kekerasan diambil pada daerah base metal, HAZ, dan weld metal, sedangkan untuk pengujian metalografi diambil pada daerah weld metal dan HAZ.

\section{Diagram Rancangan Penelitian}

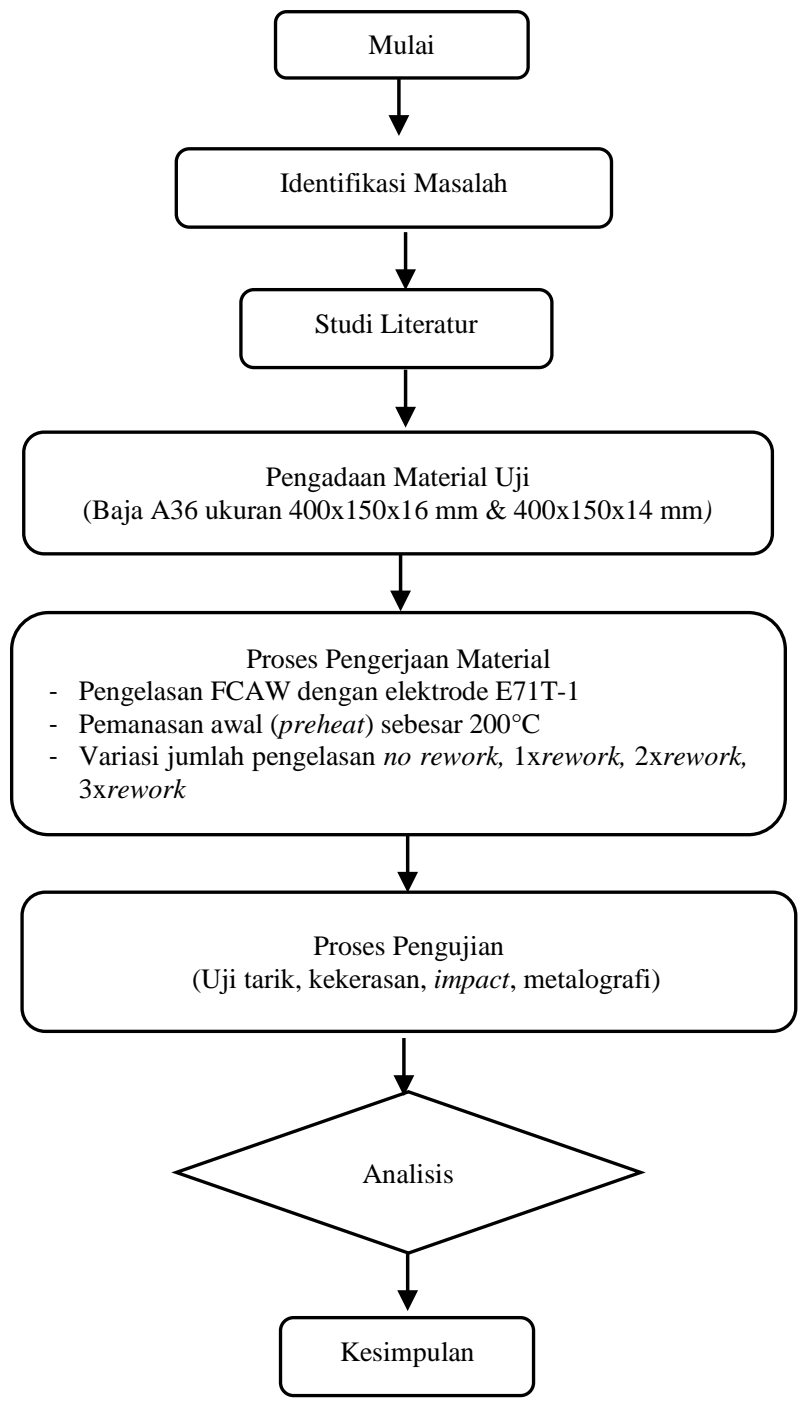

Gambar 2. Bagan Alir Penelitian

IV. HASIL DAN ANALISIS DATA

A. Pengujian Tarik

Tensile Test

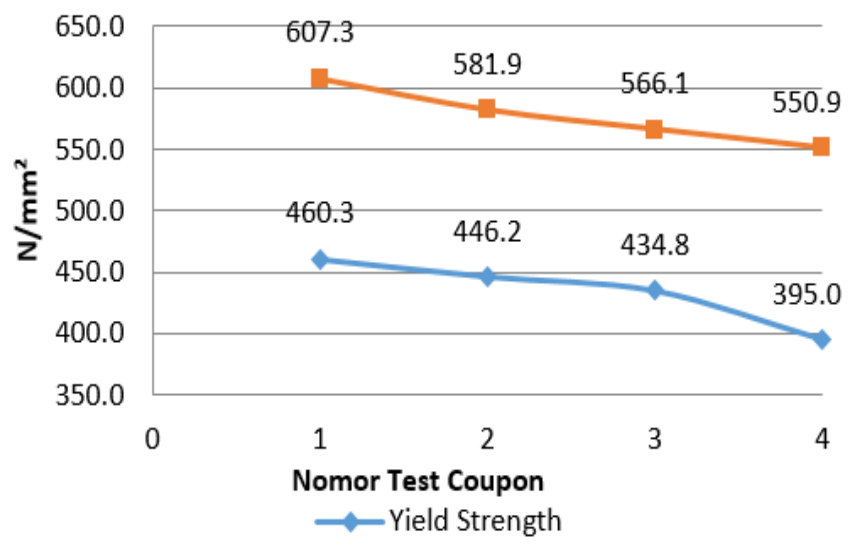

Gambar 3. Grafik Pengujian Tarik 
Pada Gambar 3 menunjukkan bahwa secara keseluruhan hasil pengujian tarik mengalami penurunan baik nilai yield strength maupun nilai ultimate tensile strength. Penurunan tersebut terjadi akibat dilakukannya pengelasan ulang pada material, akan tetapi nilai penurunan tidak terlalu signifikan. Hal tersebut menjelaskan bahwa material yang sering dilakukan pengelasan ulang akan berkurang nilai kuat tarik pada material tersebut, akan tetapi tidak terlalu signifikan karena adanya pengaruh perlakuan panas pada material berupa pemanasan awal (preheat) sebelum dilakukan pengelasan. Pemanasan awal (preheat) dapat memperlambat laju pendinginan dan memungkinkan hidrogen dapat terdifusi keluar dari logam las dan logam dasar sehingga menghasilkan struktur logam lebih ulet yang memiliki ketahanan terhadap retak lebih besar. Selain itu juga dapat mengurangi tegangan sisa dalam logam las.

\section{B. Pengujian Kekerasan}

\section{Hardness Test}

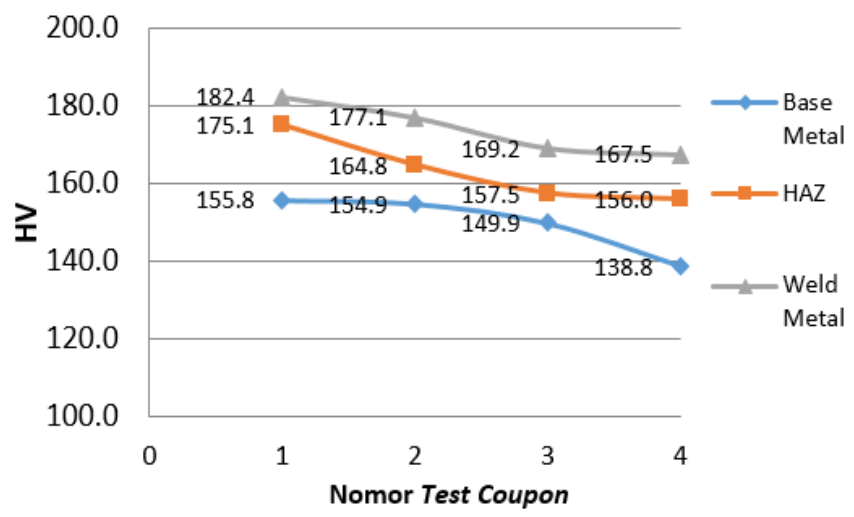

Gambar 4. Grafik Pengujian Kekerasan

Dilihat dari Gambar 4 Grafik Pengujian Kekerasan bahwa secara keseluruhan nilai kekerasan material berkurang seiring dilakukannya pengelasan ulang. Hal tersebut disebabkan material menerima pengaruh panas yang berlebih pada saat dilakukannya pengelasan ulang. Bahwa semakin banyak dilakukan pengelasan ulang maka nilai kekerasan material semakin berkurang. Hal tersebut berlaku pada keseluruhan material baik pada base metal, HAZ maupun pada weld metal. Pada Gambar 4 terlihat bahwa penurunan nilai kekerasan pada setiap pengelasan ulang tidak terlalu signifikan. Hal tersebut dikarenakan material diberikan heat treatment berupa pemanasan awal (preheat) yang dapat mengurangi perbedaan tegangan pada logam las dan logam induk sehingga penurunan nilai kekerasan tidak terlalu signifikan.

\section{Pengujian Impact}

\section{Impact Test}

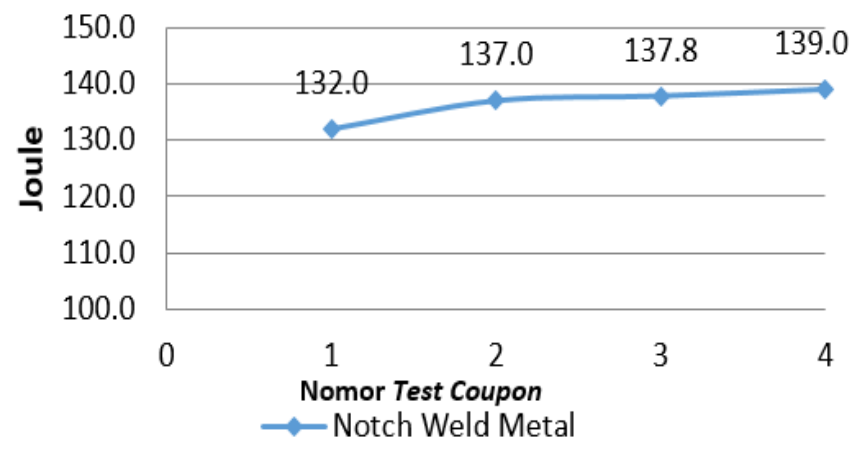

Gambar 5. Grafik Pengujian Impact
Pada Gambar 5 menunjukkan bahwa energi absorb mengalami kenaikan. Kenaikan energi absorb tersebut akibat adanya pengaruh dilakukannya pengelasan ulang pada material yang diberikan perlakukan panas berupa pemanasan awal (preheat), dimana hal tersebut dapat membuat nilai kekerasan material berkurang dan nilai energi absorb semakin naik sehingga sifat material menjadi ulet.

Hal tersebut dapat dibuktikan dengan pernyataan pada sub tentang analisis hasil pengujian kekerasan, dimana nilai kekerasan pada test coupon nomor empat (3 x rework) dibandingkan dengan test coupon nomor satu (no rework) berkurang seiring dilakukannya pengelasan ulang pada material. Dapat disimpulkan bahwa dimana material dengan nilai kekerasan material semakin menurun akibat dilakukan pengelasan ulang yang diberikan perlakuan panas berupa pemanasan awal (preheat), maka semakin naik nilai energi absorb material dan membuat material tersebut menjadi lebih ulet

\section{Pengujian Metalografi}

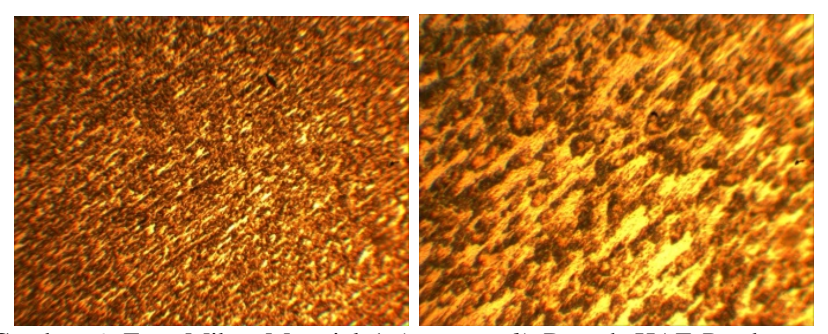

Gambar 6. Foto Mikro Material 1 (no rework) Daerah HAZ Pembesaran 100x dan 400x

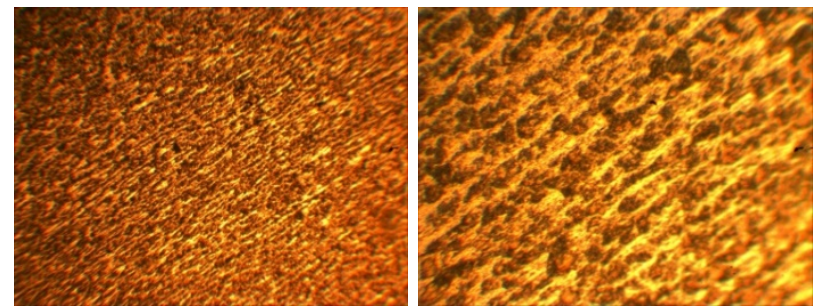

Gambar 7. Foto Mikro Material 2 (1x rework) Daerah HAZ Pembesaran 100x dan 400x

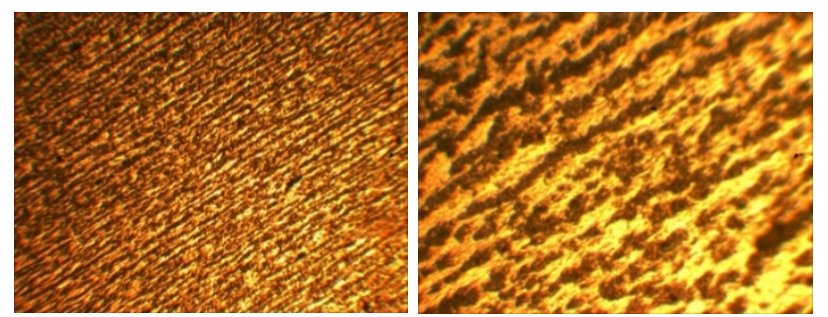

Gambar 8. Foto Mikro Material 3 (2x rework) Daerah HAZ Pembesaran 100x dan 400x

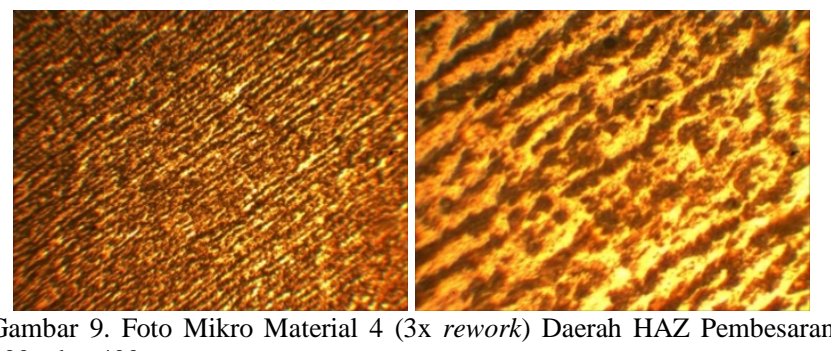

Gambar 9. Foto Mikro Material 4 (3x rework) Daerah HAZ Pembesaran 100x dan 400x

Berdasarkan hasil pengujian struktur mikro pada daerah HAZ (Heat Affected Zone), dapat diperhatikan bahwa butiran yang terbentuk terdiri dari ferrite dan pearlite, dimana ferrite butirannya berwarna terang sedangkan pearlite butirannya berwarna gelap. Jika diperhatikan pada Gambar 6, 7, 8, 9 
bahwa pada daerah HAZ baik pada material 1 (no rework), material 2 (1x rework), material 3 (2x rework) dan material 4 (3x rework) terdapat sebuah perubahan yang tidak terlalu signifikan untuk komposisi ferrite dan pearlite ukuran butirnya semakin besar.

Hal tersebut diakibatkan adanya pengaruh pada pengelasan ulang serta perubahan yang tidak terlalu signifikan diakibatkan adanya heat treatment yaitu pemanasan awal (preheat) yang dilakukan pada material sebelum dilakukan pengelasan. Dengan demikian pemanasan awal memberikan sedikit pengaruh pada pengelasan ulang ditinjau pada daerah HAZ material baja ASTM A36.
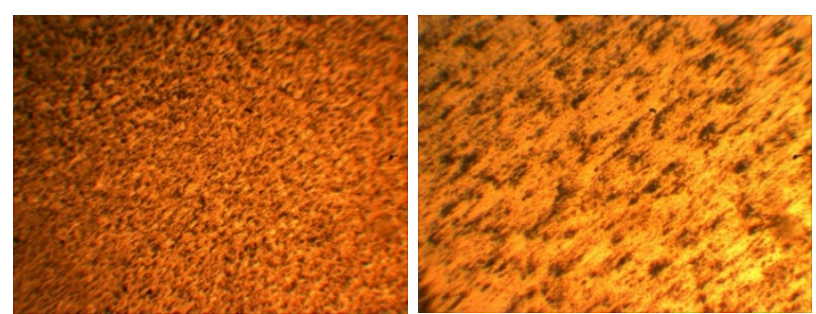

Gambar 10. Foto Mikro Material 1 (no rework) Daerah Weld Metal Pembesaran 100x dan 400x
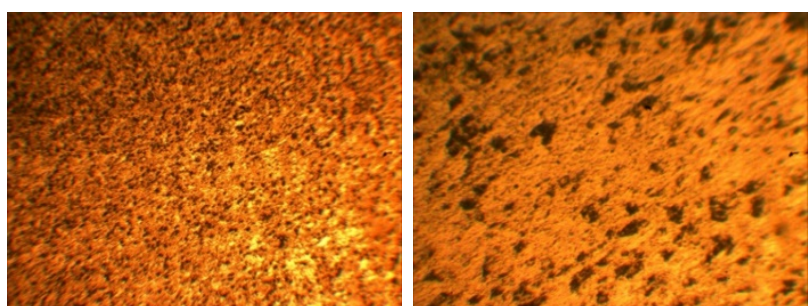

Gambar 11. Foto Mikro Material 2 (1x rework) Daerah Weld Metal Pembesaran 100x dan 400x
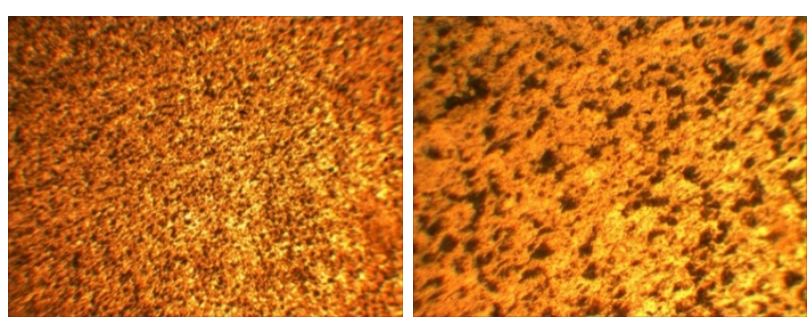

Gambar 12. Foto Mikro Material 3 (2x rework) Daerah Weld Meta Pembesaran 100x dan 400x
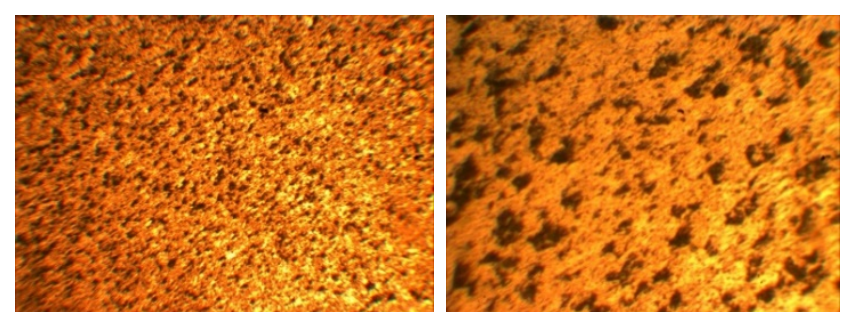

Gambar 13. Foto Mikro Material 4 (3x rework) Daerah Weld Metal Pembesaran 100x dan 400x

Berdasarkan hasil pengujian struktur mikro pada daerah weld metal. Pernyataan tersebut juga berlaku pada daerah weld metal. Jika diperhatikan pada Gambar 10, 11, 12, 13 bahwa pada daerah weld metal baik pada material 1 (no rework), material 2 (1x rework), material 3 (2x rework) dan material 4 (3x rework) terdapat sebuah perubahan yang tidak terlalu signifikan untuk komposisi ferrite dan pearlite ukuran butirnya semakin besar.

Hal tersebut diakibatkan adanya pengaruh pada pengelasan ulang serta perubahan yang tidak terlalu signifikan diakibatkan adanya heat treatment yaitu pemanasan awal (preheat) yang dilakukan pada material sebelum dilakukan pengelasan. Dengan demikian pemanasan awal memberikan sedikit pengaruh pada pengelasan ulang ditinjau pada daerah weld metal material baja ASTM A36.

Terdapat hubungan antara hasil pengujian struktur mikro dengan hasil pengujian kekerasan bahwa perbedaan besaran butir tersebut akan menghasilkan angka kekerasan yang berbeda, semakin besar ukuran butir pada material maka akan semakin kecil angka kekerasan yang dimiliki oleh material tersebut. Pernyataan tersebut mendukung hasil dari pengujian kekerasan yang dijelaskan pada Sub Bab IV.2. dimana material 1 dengan perlakuan no rework memiliki angka kekerasan yang lebih tinggi dibandingkan dengan material 4 dengan perlakuan 3x rework.

\section{E. Hubungan Keseluruhan Pengujian}

Berdasarkan keseluruhan pengujian yang telah dilakukan pada penelitian ini, terdapat keterkaitan antara pengujian satu dengan pengujian yang lain dimana hal tersebut dapat divalidasikan terhadap penelitian dalam Hall Petch Equation yang menyatakan bahwa semakin kecil ukuran butir maka semakin kecil tekanan tolakan yang dirasakan oleh dislokasi batas butir dan semakin tinggi tegangan yang diperlukan untuk menyebarkan dislokasi melalui material. Selain itu, semakin kecil ukuran butir pada material maka material tersebut memiliki angka kekerasan yang tinggi.

Dengan demikian hasil dari pengujian penelitian ini sesuai dengan Hall Petch Equation dimana nilai dari pengujian pada material 1 (no rework), material 2 (1x rework), material 3 (2x rework) dan material 4 (3x rework) didapatkan bahwa nilai hasil pengujian tarik yang semakin menurun akibat pengelasan ulang, nilai kekerasan material yang semakin menurun seiring dilakukannya pengelasan ulang, nilai energi absorb yang semakin besar atau meningkat dan ukuran butir yang semakin besar walaupun tidak terlalu signifikan perubahan ukuran butir tersebut.

Tabel 1.

Data Persentase Rata-Rata Pengujian

\begin{tabular}{cccccc}
\hline \hline \multicolumn{2}{c}{ Tanpa Prehat } & \multicolumn{2}{c}{ Dengan Prehat } & \multicolumn{2}{c}{$\begin{array}{c}\text { Prersentaese Rata- } \\
\text { rata }\end{array}$} \\
\hline $\begin{array}{c}\text { Persentase } \\
\begin{array}{c}\text { Uji } \\
\text { Kekerasan } \\
\mathbf{( \% )}\end{array}\end{array}$ & $\begin{array}{c}\text { Persentase } \\
\text { Uji Tarik } \\
(\mathbf{( \% )}\end{array}$ & $\begin{array}{c}\text { Persentase } \\
\text { Uji } \\
\text { Kekerasan } \\
\mathbf{( \% )}\end{array}$ & $\begin{array}{c}\text { Persentasi } \\
\text { Uji Tarik } \\
\mathbf{( \% )}\end{array}$ & $\begin{array}{c}\text { Uji } \\
\text { Kekerasan } \\
(\%)\end{array}$ & $\begin{array}{c}\text { Tji } \\
\text { Torik } \\
(\%)\end{array}$ \\
\hline 0.03 & 0.03 & -0.06 & -0.04 & 1.41 & 1.69 \\
-0.08 & -0.05 & -0.05 & -0.03 & -0.80 & -0.69 \\
-0.02 & -0.15 & -0.01 & -0.03 & -1.36 & -4.28 \\
\hline \hline
\end{tabular}

Berdasarkan data persentase rata-rata pengujian yang diperoleh diatas, maka pemanasan awal (preheat) berpengaruh sedikit atau tidak terlalu signifikan terhadap material yang dilakukan pengelasan ulang pada tempat yang sama. Direkomendasikan maksimal dilakukan 2 x pengelasan ulang pada material dikarenakan setelah 2 x pengelasan ulang nilai kekuatan, ketangguhan dan kekerasan material turun drastis

\section{KESIMPULAN DAN SARAN}

\section{A. Kesimpulan}

Nilai yield strength dan ultimate tensile strength mengalami penurunan seiring dilakukan pengelasan ulang, dimana pemanasan awal (preheat) berpengaruh terhadap penurunan nilai yang lebih stabil.

Terjadi penurunan nilai kekerasan pada daerah base metal, HAZ dan weld metal seiring dilakukannya pengelasan ulang. 
Penurunan nilai kekerasan yang tidak terlalu signifikan terjadi karena adanya pengaruh pemanasan awal (preheat) yang dilakukan pada setiap pengelasan ulang.

Terjadi kenaikan energi absorb seiring dilakukannya pengelasan ulang dengan diberikan perlakuan panas berupa pemanasan awal (preheat) pada material

Pemanasan awal (preheat) berpengaruh sedikit atau tidak terlalu signifikan terhadap pengelasan ulang pada ukuran butir material yang terbentuk semakin besar dan rapat.

\section{B. Saran}

Melakukan perbandingan pada salah satu material yang diberikan perlakuan panas dengan material tanpa perlakuan panas

\section{DAFTAR PUSTAKA}

[1] American Welding Society (AWS), Structural Welding Code AWS D1.1. United States of America: American Welding Society (AWS).

[2] JWES \& IWS, Teknologi Pengelasan. Tokyo, 2011.

[3] ASME Boiler and Pressure Vessel Code, Section II Materials Part A Ferrous Material Specification. New York: ASME Boiler and Pressure Vessel Code, 2017.

[4] R. S. Funderburk, "Fundamental of preheat," Welding Innovation, Pittsburgh, pp. 14-15, 1997.

[5] ASM International, ASM Metal Handbook Volume 6 Welding, Brazing and Soldering. Ohio: ASM International, 1993.

[6] American Welding Society (AWS), Welding Inspection Technology Fifth Edition. United States of America: American Welding Society (AWS), 2008.

[7] M. Kato, "Hall-petch relationship and dislocation model for deformation of ultrafine-grained and nanocrystalline metals," Mater. Trans., vol. 55, no. 1, pp. 19-24, Jan. 2014.

[8] Biro Klasifikasi Indonesia, Rules for the classification and construction, Volume VI: Rules for welding. Jakarta: Biro Klasifikasi Indonesia, 2015. 